\title{
Expression of mRNA encoding basic fibroblast growth factor (bFGF) in bovine corpora lutea and cultured luteal cells*
}

\author{
D. Stirling $\dagger$, M. R. Waterman and E. R. Simpson \\ Cecil H. and Ida Green Center for Reproductive Biology Sciences, Departments of \\ Obstetrics/Gynecology and Biochemistry, University of Texas Southwestern Medical Center, \\ Dallas, TX 75235, USA
}

\begin{abstract}
Summary. A radiolabelled cRNA was synthesized using a $1.4 \mathrm{~kb}$ cDNA complementary to mRNA encoding bovine basic fibroblast growth factor (bFGF) as a template, and used as a probe to investigate the expression of mRNA encoding bFGF in bovine ovarian tissue, and luteal cells in primary culture. Northern analysis of poly $(\mathrm{A}+)$ RNA prepared from follicles and corpora lutea of various stages revealed a major mRNA species of $7 \mathrm{~kb}$ in corpora lutea of all stages, the amount of which was higher late in the luteal phase. No hybridizable message was detectable in follicles of any size. When luteal cells were established in primary culture, expression of the $7 \mathrm{~kb}$ mRNA species was maintained. This expression was increased markedly when cells were treated with $\mathrm{LH} / \mathrm{hCG}$ or $\mathrm{Bt}_{2} \mathrm{cAMP}$. Prostaglandin F- $2 \alpha$ treatment caused a marked decrease in the basal content of this $7 \mathrm{~kb}$ mRNA, and also severely impaired the ability of LH to stimulate this expression.
\end{abstract}

Keywords: ovary; corpus luteum; RNA; bFGF; cow

\section{Introduction}

The rapid angiogenesis occurring during the development of the corpus luteum (CL) has long been recognized (Bassett, 1943; McClellan et al., 1975). Within $48 \mathrm{~h}$ of ovulation, the previously avascular granulosa layer has developed a rich network of sinusoidal vessels which supply the growing CL. Using the chick chorioallantoic membrane assay, Jakob et al. (1985) demonstrated that bovine CL grafts exhibited a high degree of angiogenic activity. More recently, Redmer $e t$ al. (1988) demonstrated that conditioned medium from bovine luteal cultures exhibited angiogenic activity which could be enhanced by stimulating the luteal cultures with LH, and that this enhancement could be blocked by PGF-2 $\alpha$.

Basic fibroblast growth factor (bFGF) is a peptide of 146 amino acids, which stimulates angiogenesis in a number of different tissues. This peptide has been identified in a wide range of highly vascularized tissues, including the bovine CL (Gospodarowicz et al., 1985). It stimulates proliferation of luteal vascular endothelial cells in vitro (Gospodarowicz et al., 1986) and is produced in cultured bovine granulosa cells (Neufeld et al., 1987). These observations have led to the suggestion that bFGF is a major angiogenic factor in the bovine CL. We have therefore examined the expression of mRNA encoding bFGF in ovarian follicles and CL of cows throughout the oestrous cycle, as well as in primary cultures of luteal cells, in an attempt to understand the

\footnotetext{
*This work was presented, in part, as the 'Walpole Lecture' to the Society for the Study of Fertility, July 1988.

†Present address: Imperial Cancer Research Fund, Molecular Pharmacology and Drug Metabolism Laboratory, Hugh Robson Building, George Square, Edinburgh EH8 9XD, UK.
} 
regulation of expression of this peptide, and its possible involvement in the process of angiogenesis in the CL.

\section{Materials and Methods}

Tissues. Ovaries were obtained from non-pregnant cows at slaughter. Only follicles which appeared healthy and nonatretic on the basis of integrity of the membrana granulosa under transillumination (Rajakoski, 1960; Marion et al., 1968; Rodgers et al., 1987) were used. Antral follicles of a range of sizes were collected, and subsequently pooled into groups based upon their diameter. Pools of at least 10 follicles per group were used, in an attempt to allow for variability within follicles. CL were classified into four groups (I, II, III and IV), on the basis of gross morphology according to the method of Ireland et al. (1980), corresponding to the early, early-mid, mid-late and regressing stages of the luteal phase respectively.

Cells. All luteal cell preparations and culture were carried out in McCoy's 5A medium with 1.25 M-glutamine (Grand Island Biological Co., Grand Island, NY, USA) containing penicillin (10 U/ml), streptomycin sulphate $(0.1 \mathrm{mg} / \mathrm{ml})$, transferrin $(1 \mathrm{ng} / \mathrm{ml})$ and sodium selenate $(1 \mathrm{pg} / \mathrm{ml})$. Stage II corpora lutea (10-12 per preparation) were sliced on a Stadie Riggs hand microtome, and digested in McCoy's 5A culture medium containing $0.2 \%$ collagenase and $2.5 \%$ fetal bovine serum. This digestion was carried out in a shaking water bath at $37^{\circ} \mathrm{C}$ for $3 \times 40 \mathrm{~min}$. At the end of each $40 \mathrm{~min}$ incubation, the supernatant was removed and the remaining tissue incubated with fresh medium and enzyme. The first supernatant was discarded. The cells from the second two incubations were collected by centrifugation, washed in collagenase-free medium, pooled, plated at a density of $5 \times 10^{6} \mathrm{cells} / \mathrm{ml}(100 \mathrm{~mm}$ culture dishes, Falcon Plastics, Cockeysville, MD, USA $)$ and incubated for $5 \mathrm{~h}$ at $37^{\circ} \mathrm{C}\left(95 \%\right.$ air, $\left.5 \% \mathrm{CO}_{2}\right)$ to deplete the suspension of fibroblasts: cells which attached in this period produced undetectable amounts of progesterone when incubated with $\mathrm{LH}$ or $\mathrm{Bt}_{2}$ cAMP for $24 \mathrm{~h}$, and exhibited a characteristic fibroblastic appearance. Unattached cells $(75-80 \%$ of total; $>90 \%$ viability by trypan blue exclusion) were then re-plated at a density of $10^{6} \mathrm{cells} / \mathrm{ml}$. After an overnight incubation, cells had attached to the culture dishes, and were washed for 5-6 h in serum-free McCoy's medium. Cells were then incubated for $24 \mathrm{~h}$ in serum-free medium alone or supplemented with bovine LH, PGF- $\alpha$ or both. At the end of this incubation period, medium was removed for progesterone assay, and RNA was prepared from the cells. Cells used for the characterization of progesterone production were lysed in $0.5 \mathrm{M}-\mathrm{NaOH}$ and assayed for protein using the method of Lowry et al. (1951). Progesterone in the culture medium was assayed in duplicate without extraction using a commercial radioimmunoassay system (Radioassay Systems Laboratores, Inc., Carson, CA, USA). The limit of sensitivity of the assay was $50 \mathrm{pg} /$ tube. Inter- and intra-assay coefficients of variation were $13 \%$ and $9 \%$, respectively.

RNA isolation. RNA was prepared essentially by the method of MacDonald et al. (1987). Groups of follicles and segments of luteal tissue were homogenized in $4 \mathrm{M}$-guanidinium thiocyanate solution containing $5 \mathrm{~mm}$-sodium citrate, $0.1 \mathrm{M} \beta$-mercaptoethanol and $0.5 \%$ Sarkosil. Luteal cells were removed from culture dishes by the addition of ice-cold guanidinium thiocyanate solution, followed by vigorous scraping with a rubber policeman, and disrupted by forcing through a narrow gauge needle. Particulate matter was removed by centrifugation $\left(12000 \mathrm{~g}, 15 \mathrm{~min}, 4^{\circ} \mathrm{C}\right)$ and the supernatant was centrifuged through a $1.5 \mathrm{ml} 5.7 \mathrm{M}-\mathrm{CsCl}$ cushion $\left(25000 \mathrm{~g}, 16 \mathrm{~h}, 23^{\circ} \mathrm{C}\right.$, Beckman $\mathrm{SW} 60$ rotor). The RNA pellet was resuspended in diethylpyrocarbonate-treated water (Maniatis et al., 1982), precipated by the addition of 0.1 volume $3 \mathrm{M}$-sodium acetate and ethanol to $70 \%$, washed in $70 \%$ ethanol, and redissolved in water. Poly(A+) mRNA was prepared from the samples by affinity chromatography (Maniatis et al., 1982) on oligo(dT)-cellulose (Pharmacia P-L. Biochemicals, Uppsala, Sweden). RNA concentation was determined by measurement of absorbance at $260 \mathrm{~nm}$ for diluted aliquants of both total and poly $(\mathrm{A}+)$ RNA.

Northern blotting. RNA samples were subjected to electrophoresis through $1 \%$ agarose gells containing formaldehyde $(6 \%)$ using a $20 \mathrm{~mm}$-morpholinopropanesulphonic acid buffer (MOPS: $\mathrm{pH}$ 7) containing 5-mm sodium acetate and $0.1 \mathrm{~mm}$-EDTA (Maniatis et al., 1982). The RNA was then electroblotted ( $30 \mathrm{~V}$, overnight) to a nylon membrane (Zeta-Probe, Bio-Rad Laboratories, Richmond CA, USA) in 10-mM-Tris, $5 \mathrm{~mm}$-sodium acetate, and $0.5 \mathrm{~mm}$-EDTA. Prehybridization was carried out at $65^{\circ} \mathrm{C}$ in $50 \%$-formamide, $50 \mathrm{~mm}$-Tris- $\mathrm{HCl}(\mathrm{pH} \mathrm{7.5)}$, $0 \cdot 1 \%$-sodium phosphate, $1 \%$-SDS, $0.2 \%$-polyvinylpyrolidone, $0.2 \%$ Ficol, $5 \mathrm{~mm}$-EDTA and denatured salmon sperm DNA $(150 \mu \mathrm{g} / \mathrm{ml})$.

A radiolabelled cRNA was synthesized utilizing a $1.4 \mathrm{~kb}$ cDNA (Abraham et al., 1986) complementary to mRNA encoding bovine bFGF as a template. This cDNA was sub-cloned into the poly-linker region of the "Bluescript" cloning vector (Stratagene, La Jolla, CA, USA), allowing the synthesis of ${ }^{32}$ P-labelled cRNA complementary to native $\mathrm{mRNA}$ encoding bFGF. These reactions utilized T7 RNA polymerase, and were carried out in the presence of $40 \mathrm{mM}$-Tris- $\mathrm{HCl}(\mathrm{pH} 8), 8 \mathrm{~mm}-\mathrm{MgCl}_{2}, 2 \mathrm{mM}$-spermidine, $50 \mathrm{mM}-\mathrm{NaCl}, 400 \mu \mathrm{M}$ of each cold rNTP (rATP, rGTP, rCTP, rUTP), and $50 \mathrm{mCi} \alpha-\mathrm{UT}^{32} \mathrm{P}$ (sp. act. $800 \mathrm{Ci} / \mathrm{mmol}$ ).

Hybridizations were carried out at $65^{\circ} \mathrm{C}$ in the same buffer as prehybridizations, but containing denatured labelled cRNA $\left(1 \times 10^{6}\right.$ c.p.m. $\left./ \mathrm{ml}\right)$. Blots were then washed twice in $2 \times \operatorname{SSC}(0 \cdot 3 \mathrm{M}-\mathrm{NaCl}, 30 \mathrm{~mm}$-sodium citrate $) ; 0.1 \%$ SDS for $20 \mathrm{~min}$ each and twice in $0.1 \times \mathrm{SSC}(15 \mathrm{~mm}-\mathrm{NaCl}, 1.5 \mathrm{~mm}$-sodium citrate); $0.1 \%$ SDS for $15 \mathrm{~min}$ each, again at $65^{\circ} \mathrm{C}$. They were then blotted dry, wrapped in plastic film, and subjected to autoradiography. 


\section{Results}

\section{Fresh tissue}

When radiolabelled bFGF cDNA was used as a hybridization probe, no message was detected in any samples of ovarian RNA (results not shown), suggesting that levels of expression were very low. However, Northern analysis using the cRNA probe revealed a major mRNA species of $7 \cdot 3 \mathrm{~kb}$ and a second species of $3.7 \mathrm{~kb}$ in corpora lutea of all stages (Fig. 1). Furthermore, the expression of this mRNA (particularly the $7.3 \mathrm{~kb}$ species) appeared to be higher in CL from ovaries that were in the later stages of the cycle. No mRNA encoding bFGF was detectable in follicles of any size (Fig. 1). This result demonstrates the advantage of using cRNA as a hybridization probe in Northern analysis of mRNA species present in low amounts.

\section{Luteal cell cultures}

The $7.3 \mathrm{~kb}$ mRNA species was detectable in luteal cells cultured under basal conditions. The levels of this species were higher than in fresh tissue, and markedly induced by hCG $(100 \mathrm{i} . \mathrm{u} . / \mathrm{ml})$ or $\mathrm{Bt}_{2} \mathrm{cAMP}(1 \mathrm{mM}$ ) treatment (Fig. 2). The $3.7 \mathrm{~kb}$ mRNA species was undetectable in cells in culture under any conditions. LH caused a dose-dependent increase in progesterone production which could not be antagonized by PGF- $2 \alpha(1 \mu \mathrm{g} / \mathrm{ml}$; Fig. 3$)$. LH also caused a dose-dependent increase in the levels of mRNA encoding bFGF, similar to the response of the cells in terms of progesterone secretion (Fig. 4). In contrast to its lack of effect on progesterone accumulation, PGF-2 $\alpha$ markedly inhibited both basal and LH-stimulated expression of bFGF mRNA, although this inhibition was only partial for the highest doses of LH (Fig. 4).

\section{Discussion}

The data presented here demonstrate the expression of mRNA encoding bFGF in bovine luteal tissue, and suggest that bFGF, which has previously been isolated from the bovine $\mathrm{CL}$, is produced locally within that tissue. The sizes of the mRNA species encoding bFGF detected in this study correspond well to those previously reported for a range of tissues, (see Baird et al., 1986, for review). Neufeld et al. (1987) reported the expression of mRNA encoding bFGF in cultured bovine granulosa cells, and suggested a role for locally produced bFGF in follicular maturation and ovulation. However, we were unable to detect any hybridizable message in RNA isolated from follicles of a wide range of sizes (perhaps suggesting that the granulosa cells used by Neufeld et al. (1987) had luteinized in culture). This observation, together with previous reports that bFGF inhibits the FSH-mediated induction of granulosa LH receptors (Schomberg et al., 1983) and attenuates the FSH-induced increase in granulosa cell aromatase activity (Baird et al., 1986; Adashi et al., 1988), is more consistent with a role for this peptide in luteal rather than follicular development.

In view of the proposed involvement of bFGF in luteal angiogenesis (Baird et al., 1986), it is perhaps surprising that the highest levels of mRNA encoding bFGF were observed not in CL of Stages I or II, which are undergoing the most rapid capillary growth (McClellan et al., 1975), but late in the luteal phase, when $C L$ are beginning to regress. There are two apparent explanations for the disparity between the levels of mRNA encoding bFGF and the observed angiogenesis in vivo. (1) bFGF concentrations may never be limiting for angiogenesis, and the rate at which that process proceeds could be dependent on other factors, such as the abundance of bFGF receptors on the vascular endothelial cells. (2) The concentrations of bFGF available to receptors are not determined by the rate of bFGF production, but by its release. Since the peptide encoded by bFGF mRNA does not contain a conventional signal sequence (Abraham et al., 1986), it is unclear how bFGF is released from the cell. Given the high affinity of bFGF for heparin (Gospodarowicz, 1987), Neufeld 


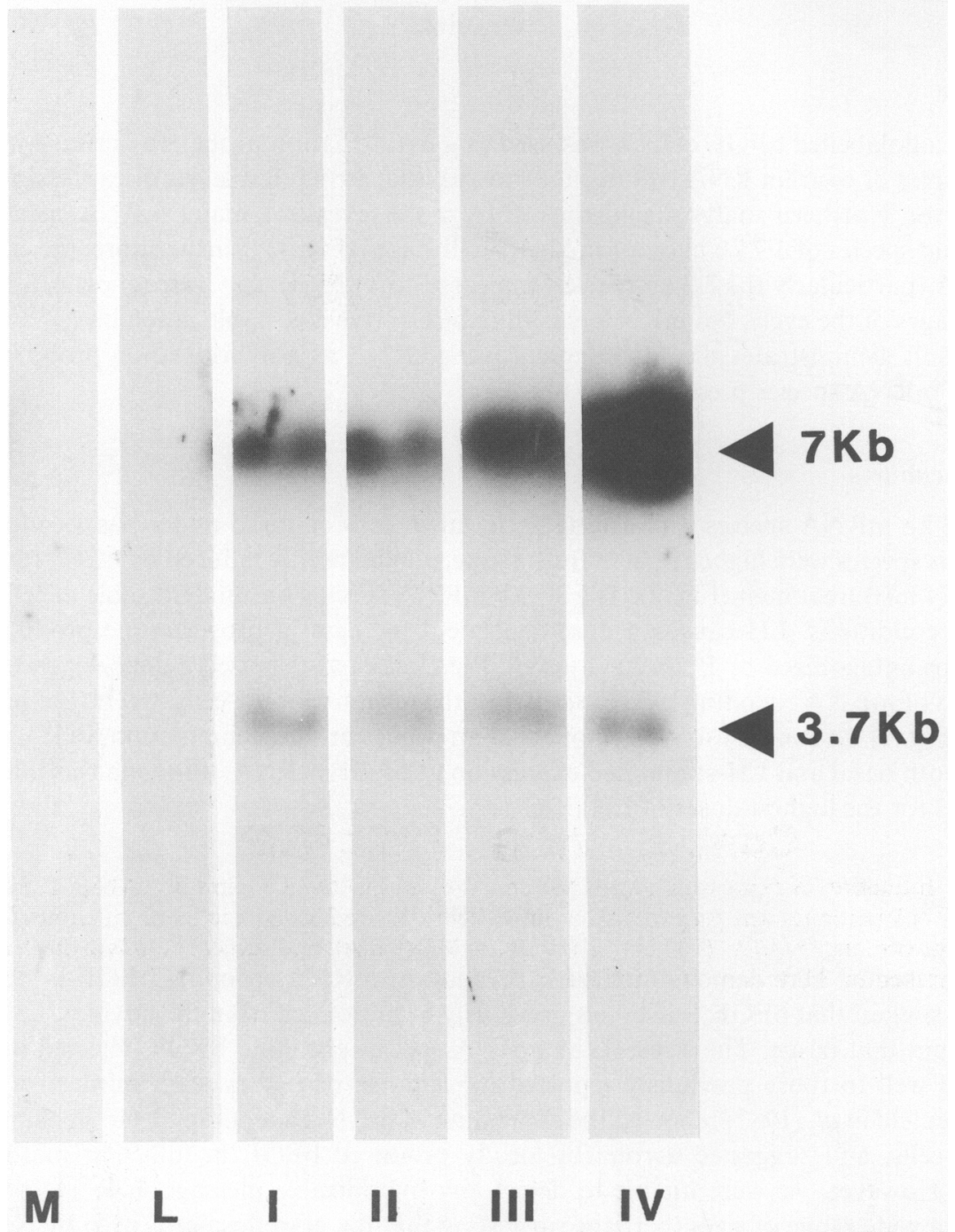

Fig. 1. Expression of mRNA encoding bFGF in ovarian tissue. Poly $(A+)$ RNA $(25 \mu \mathrm{g}$ per lane) was prepared from medium sized (M) and large (L) follicles, and corpora lutea designated I, II, III and IV, corresponded to the early, early-mid, late-mid and regressing stages of the luteal phase (Ireland et al., 1980), and subjected to Northern analysis as described in 'Materials and Methods'.

et al. (1987) suggested that it may be released in association with heparin sulphate proteoglycans. The synthesis and secretion of these components of the extracellular matrix are under the influence of steroids, gonadotrophins, IGF-I, prostaglandins, cyclic nucleotide and bFGF (Yanagishita et al., 1981; Adashi et al., 1986), and so any of these agents could possibly modulate bFGF secretion. Whether such complexed bFGF would be biologically active is also uncertain. Mormede et al. (1985) identified the presence of high-molecular weight $(70000)$ forms of immunoreactive bFGF, leading to speculation that the bioavailability of the active form of bFGF $\left(M_{r} 16000\right)$ may be highly regulated at the level of enzymic cleavage of a larger precursor molecule (Baird et al., 1986).

In the present study the $3.7 \mathrm{~kb}$ mRNA species was undetectable in luteal cells in culture. This may be due to the use of total RNA in the Northern blots of the cell culture experiments. As only 


\section{Control hCG Bt2CAMP}

Fig. 2. Induction of expression of mRNA encoding bFGF by hCG and $\mathrm{Bt}_{2} \mathrm{cAMP}$. RNA ( $20 \mu \mathrm{g}$ total RNA per lane) was prepared from luteal cells cultured for $24 \mathrm{~h}$ in medium alone (Control) or in the presence of $\mathrm{hCG}(100 \mathrm{i} . \mathrm{u} . / \mathrm{ml})$ or $\mathrm{Bt}_{2} \mathrm{cAMP}(1 \mathrm{mM})$, and subjected to Northern analysis as described in 'Materials and Methods'.

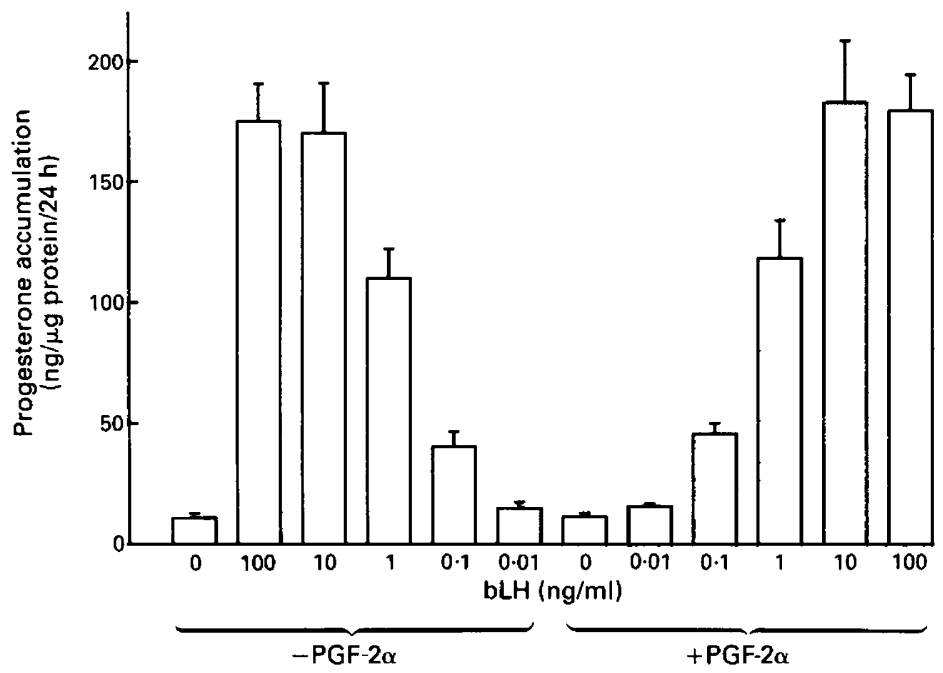

Fig. 3. Effect of PGF-2 $\alpha$ on basal and LH-stimulated progesterone accumulation. Luteal cells were incubated for $24 \mathrm{~h}$ with a range of concentations of $\mathrm{LH}$ in the absence or presence of PGF- $2 \alpha(1 \mu \mathrm{g} / \mathrm{ml})$. Values are mean \pm s.e.m. of 3 replicate experiments, each condition being tested in triplicate. 


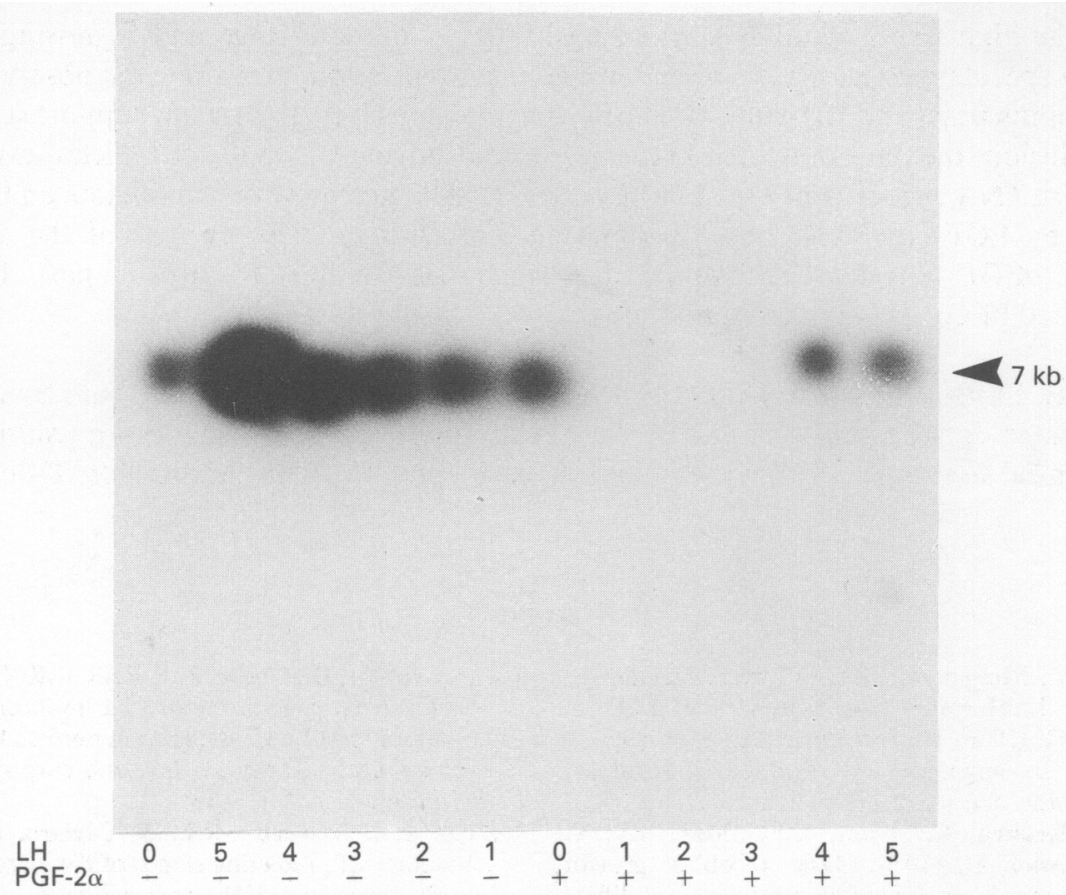

Fig. 4. Effect of PGF-2 $\alpha$ on basal and LH-stimulated expression of mRNA encoding bFGF. RNA ( $20 \mu \mathrm{g}$ total RNA per lane) was prepared from luteal cells incubated for $24 \mathrm{~h}$ with a range of concentrations of LH (1-5 representing $0 \cdot 01-100 \mathrm{ng} / \mathrm{ml}$ in 10-fold increments) in the absence or presence of PGF- $2 \alpha(1 \mu \mathrm{g} / \mathrm{ml})$, and subjected to Northern analysis as described in 'Materials and Methods'.

$1-5 \%$ of total RNA is mRNA, a species just detectable in a sample of mRNA would have to be induced 20-100-fold to still be detectable in the same amount of total RNA. It would appear that the $3.7 \mathrm{~kb}$ mRNA species was not induced to this extent.

The detection of the $7 \cdot 3 \mathrm{~kb}$ mRNA species in cultured cells suggests that higher amounts of this species were present in cultured cells than in fresh tissue. The reasons for this observation are unclear, but may represent either a stimulation of expression, perhaps by the trauma of cell preparation, or the removal of some inhibition, for instance high concentations of bFGF associated with the extracellular matrix (see above). These elevated levels of expression were not maximal, however, and could be stimulated further. The increase in amounts of the $7.3 \mathrm{~kb}$ species alone may suggest that its expression and that of the $3.7 \mathrm{~kb}$ mRNA species are regulated differently.

Redmer $e t$ al. (1988) reported that the angiogenic activity present in luteal tissue-conditioned medium could be increased significantly by the addition of $\mathrm{LH}$, and that this increase could be prevented by simultaneous addition of PGF- $2 \alpha$. In the present study, when luteal cells were treated with hCG, $\mathrm{LH}$ or $\mathrm{Bt}_{2} \mathrm{cAMP}$ in vitro, both progesterone production and the amounts of mRNA encoding bFGF (Figs 3 and 4) were increased. PGF-2 $\alpha$ markedly reduced the amounts of $m$ RNA encoding bFGF, and the ability of LH to increase these levels (Fig. 4). However, PGF-2 $\alpha$ had no effect on basal or $\mathrm{LH}$-stimulated progesterone production. PGF- $2 \alpha$ has been reported to stimulate progesterone production in isolated small luteal cells by a mechanism presumably mediated by increases in protein kinase C (Brunswig et al., 1986; Alila et al., 1988; Davis et al., 1988). Progesterone production by large luteal cells or mixed cell populations, however, has been reported to be reduced (Pate \& Condon, 1984; Alila et al., 1988) or unaffected by PGF-2a (Alila et al., 1988; Davis et al., 1988). The present results are therefore within the range of previous reports. 
Given the high levels of mRNA encoding bFGF in the late stage and regressing $C L$, it is tempting to speculate on a role for bFGF in the luteal regression. However, the observation that PGF-2 $\alpha$ inhibits basal and LH-stimulated bFGF expression (Fig. 4) does not support such a role.

In conclusion, the data presented here suggest that bovine $\mathrm{CL}$, but not follicles, express high amounts of $\mathrm{mRNA}$ encoding bFGF. LH/hCG, via cAMP, increases this expression, and this effect is blocked by PGF-2 $\alpha$. These observations, together with previous reports of the angiogenic capacity of bFGF, suggest that the rapid angiogenesis of the $C L$ may, in part, be due to LH-stimulated bFGF production in that organ.

We thank Dr Brad Ozanne, Department of Microbiology, University of Texas Southwestern Medical Center, for the generous gift of the bovine bFGF cDNA, and Lakshmiswari Ravi for expert technical assistance. This work was funded in part by NIH grants Nos. HD13235 and DK28350.

\section{References}

Abraham, J.A., Mergia, A., Whang, J.L., Tumolo, A., Friedman, J., Hjerrild, K.A., Gospodarowicz, D. \& Fiddes, J.C. (1986) Nucleotide sequence of a clone encoding the angiogenic protein, basic fibroblast growth factor. Science, $N Y 233,545-548$.

Adashi, E., Resnick, C., Croft, C.S., May, J.V. \& Gospodarowicz, D. (1988) Basic fibroblast growth factor as a regulator of ovarian granulosa cell differentiation: A novel non-mitogenic role. Molec, cell. Endocrinol. 55, 7-14.

Adashi, E.Y., Resnick, C.E., Svoboda, M.E., Van Wyk, J.J., Hascall, V.C. \& Yanagishita, M. (1986) Independent and synergistic actions of somatomedin-C in the stimulation of proteoglycan biosynthesis by cultured granulosa cells. Endocrinology 118, 456-458.

Alila, H.W., Dowd, J.P., Corradino, R.A., Haris, W.V.\& Hansel, W. (1988) Control of progesterone production in small and large bovine luteal cells separated by flow cytometry. J. Reprod. Fert. 82, 645-655.

Baird, A., Esch, F., Mormede, P., Ueno, N., Ling, N., Bohlen, P., Ying, S., Werenberg, W. \& Guillemin, R. (1986) Molecular characterization of fibroblast growth factor: distribution and biological activities in various tissues. Recent Prog. Horm. Res. 42, 143-200.

Bassett, D.L. (1943) The changes in the vasculature of the albino rat during the estrous cycle. Am. J. Anat. 73, 251-258.

Brunswig, F., Mukhopadhyay, A.K., Budnick, L.T., Bohnet, H.G. \& Leidenberger, F.A. (1986) Phorbol ester stimulates progesterone production by isolated bovine luteal cells. Endocrinology 118, 743-749.

Davis, J.S., Alila, H.W., West, L.A., Corradino, R.A. \& Hansel, W. (1988) Acute effects of prostaglandin $F-2 \alpha$ on inositol phospholipid hydrolysis in large and small cells of the bovine corpus luteum. Molec. cell. Endocrinol. 58, 43-50.

Gospodarowicz, D. (1987) Isolation and characterization of basic fibroblast growth factor. Methods Enzymol. 147, 106-109.

Gospodarowicz, D., Cheng, J., Lui, G.M., Baird, A., Esch, F. \& Bohlen, P. (1985) Corpus luteum angiogenic factor is related to fibroblast growth factor. Endocrinology 117, 2382-2391.
Gospodarowicz, D., Cheng, J. \& Fujii, D.K. (1986) Effect of fibroblast growth factor and lipoproteins on the proliferation of endothelial cells derived from bovine adrenal cortex, brain cortex, and corpus luteum. $J$. Cell Physiol. 127, 121-136.

Ireland, J.J., Murphee, R.L. \& Coulson, P.B. (1980) Accuracy of predicting stages of the estrous cycle by gross appearance of the corpus luteum. J. Anim. Sci. 27, 451-465.

Jakob, W., Jentzsch, J.W., Baruersberger, B. \& Oehme, P. (1985) Demonstration of angiogenic activity in the corpus luteum of cattle. Exp. Pathol. 13, 231-239.

Lowry, O.H., Rosebrough, N.J., Farr, A.L. \& Randall, R.J. (1951) Protein measurements with the folin phenol reagent. J. biol. Chem. 193, 265-275.

MacDonald, R.J., Swift, G.H., Przylsyla, A.E. \& Chirgwin, J.M. (1987) Isolation of RNA using guanidinium salts. Methods Enzymol. 152, 219-227.

Maniatis, T., Fritsch, E.F. \& Sambrook, J. (1982) Molecular Cloning: A Laboratory Mannual. Cold Spring Harbor Laboratory, Cold Spring Harbor.

Marion, G.B., Gier, H.T. \& Choudary, J.B. (1968) Micromorphology of the bovine ovarian follicular system. J. Anim. Sci. 27, 45 I-465.

McClellan, M.C., Diekman, M.A., Abel, J.H. \& Niswender, G.D. (1975) Luteinizing hormone, progesterone and the morphological development of normal and superovulated corpora lutea in sheep. Cell Tiss. Res. 164, 291-307.

Mormede, P., Baird, A. \& Pigeon, P. (1985) Immunoreactive fibroblast growth factor (FGF) in rat tissues: molecular weight forms and the effects of hysterectomy. Biochem. Biophys. Res. Commun. 128, 1108-1113.

Neufeld, G., Ferrara, N., Schweigerer, L., Mitchell, R. \& Gospodarowicz, D. (1987) Bovine granulosa cells produce basic fibroblast growth factor. Endocrinology 121, 597-603.

Pate, J.L. \& Condon, W.A. (1984) Effects of prostaglandin F-2 $\alpha$ on agonist induced progesterone production in cultured bovine luteal cells. Biol. Reprod. 31, $427-435$.

Rajakoski, E. (1960) The ovarian follicular system in sexually mature heifers, with special reference to 
seasonal, cyclical and left-right variations. Acta endocr., Copenh., Suppl. 52, 7, abstr.

Redmer, D.L., Grazul, A.T., Kirsch, J.D. \& Reynolds, J.P. (1988) Angiogenic activity of bovine corpora lutea at several stages of luteal development. $J$. Reprod. Fert. 82, 627-634.

Rodgers, R.J., Waterman, M.R. \& Simpson, E.R. (1987) Levels of messenger ribonucleic acid encoding cholesterol side chain cleavage cytochrome P-450, $17 \alpha$-hydroxylase cytochrome P-450, adrenodoxin, and low density lipoprotein receptor in bovine follicles and corpora lutea throughout the ovarian cycle. Molec. Endocrinol. 1, 274-279.
Schomberg, D., May, J.V. \& Mondschein, J. (1983) Interactions between hormones and growth factors in the regulation of granulosa cell maturation in vitro. $J$. Steroid Biochem. 19, 291-295.

Yanagishita, M., Hascall, V. \& Rodbard, D. (1981) Biosynthesis of proteoglycans by rat granulosa cells in vitro: modulation by gonadotropins, steroid hormones, prostaglandins and a cyclic nucleotide. Endocrinology 109, 1641-1649.

Received 15 December 1989 